\title{
INHERITANCE OF SOME QUANTITATIVE CHARACTERS IN BREAD WHEAT (Triticum aestivum L.)
}

\author{
Ismail Hussain Ali \\ College of Agriculture, Salahaddin University. Iraq \\ E-mail: dr.ismail@ymail.com
}

\begin{abstract}
In this experiment, the means of the six populations $\left(\mathrm{P}_{1}, \mathrm{P}_{2}, \mathrm{~F}_{1}, \mathrm{~F}_{2}, \mathrm{BC}_{1}\right.$ and $\left.\mathrm{BC}_{2}\right)$ of each of two bread wheat crosses; Mexipak $\times$ Acsad- 8 and Ipa- $99 \times$ Attla were used to estimate gene effects, component of variance and heterosis for some quantitative traits viz: Plant height, days to heading, flag leaf area, spike length, spikes/plant, grains no./spike, biomass yield/plant, grain yield/plant and harvest index. These generations were produced during two growing seasons, 2009-2010 and 2010-2011. The generations were grown in a Randomized Complete Block Design with six replications at the Research Field of the College of Agriculture, Salahaddin University, Erbil, Iraq. Genetic analysis was performed using the joint scaling test based on three and six parameter models. The results revealed that inheritance of the traits could not be explained by additive-dominance model. Additive and dominance gene effects were significant for most traits in both crosses due to different origins of the parents. The values of (dominance $\times$ dominance) were greater than (additive $\times$ additive) and (additive $\times$ dominance) of most studied traits in both crosses in addition to greater values of dominance gene effect than the additive in most traits. It was suggested that selection all of them should be effective in advanced segregating generations due to epistatic gene effects. High narrow and broad sense heritability (0.94) was obtained for flag leaf area in Mexipak $\times$ Acsad- 8 cross, while high narrow sense heritability (0.86) and high broad sense heritability (0.98) were obtained for spike length and flag leaf area in Ipa- $99 \times$ Attla, so the early generation testing and selection might be recommended for these traits. Heterosis was found to be positive for most traits in both crosses.
\end{abstract}

Keywords: Bread Wheat, Generation Mean Analysis, Components of Variance, Heterosis.

Received: 28/1/2013, Accepted: 30/9/2013.

\section{INTRODUCTION}

Wheat grain yield can be improved through indirect selection on the basis of yield components; it is a complex character made up of the interaction between different yield components and environmental effects. Because of these complex interactions it is difficult to improve yield through breeding of the early generations if yield be the only factor recorded, suggesting that component characters should also be used as selection criteria for yield improvement. This is the reason why it is necessary to know the genetic architecture of yield components (Misra et al., 1994). Increase in one component might have positive or negative effect on other components. This occurrence is direct consequence of their interdependence during ontogenetic development of plants which is reflected through genetic correlations and compensation abilities (Grafius, 1978). The choice of an efficient breeding program depends to a large extent on the knowledge of gene action involved in the expression of the character. One of the most appropriate methods of genetic analysis is the generation mean analysis. As it was outlined by Kearsey and Pooni (1996), generation 
mean analysis is a useful technique in plant breeding for estimating main gene effects additive, dominance, additive $\times$ additive, additive $\times$ dominance, and dominance $\times$ dominance interactions responsible for inheritance of quantitative characters. It helps us in understanding the performance of the parents used in crosses and potential of crosses to be used either for heterosis exploitation or pedigree selection (Sharma and Sain, 2003). Besides gene effects, breeders would also like to know how much of the variation in a crop is genetic and to what extent this variation is heritable because efficiency of selection mainly depends on additive genetic variance, influence of the environment and interaction between genotype and environment (Eshghi and Akhundova, 2010).

Sufficient understanding of the inheritance of quantitative characters and information about heritability of grain yield and their components is essential to develop an efficient breeding strategy (Kumbhar and Larika, 1989). Generation mean analysis belongs to the quantitative biometric methods based on measurements of phenotypic performances of certain quantitative characters on as many as possible plant individuals in basic experimental breeding generations (parental, filial, backcross and segregation generations). Estimates of gene effects based on analysis of generation means, Singh and Subedar (1992) found that the contribution of additive gene effects were important in the inheritance of number of grains/spike and 100-grain weight, whereas the dominance gene effects contributed significantly for grain weight of spike and yield/plant, among the epistatic effects, additive $\times$ additive interactions were of considerable importance for all the characters. Munir et al. (2007) reported that additive, dominance and epistatic effects were involved in the inheritance of yield and yield components and the characters days to heading, grain weight per spike and harvest index were controlled by additive genes coupled with high heritability.

The present study was carried out to provide information about gene effects and available genetic variability for the most important quantitative characters of bread wheat for further improvement of grain yield.

\section{MATERIALS AND METHODS}

The experimental material was composed of four cultivars of bread wheat viz: Mexipak, Acsad- 8, Ipa- 99 and Attla. Generation mean analysis was carried out on the six basic populations $\left(\mathrm{P}_{1}, \mathrm{P}_{2}, \mathrm{~F}_{1}, \mathrm{~F}_{2}, \mathrm{BC}_{1}\right.$ and $\left.\mathrm{BC}_{2}\right)$ of each of two combinations of the parental cultivars, Mexipak $\times$ Acsad- 8 and Ipa- $99 \times$ Attla. The parents of the respective crosses as the male parent and the $\mathrm{F}_{1}$ generation as the female parent and effected back crosses to produce the $\mathrm{BC}_{1}$ and $\mathrm{BC}_{2}$ generations and the $\mathrm{F}_{1}$ hybrids were naturally selfed to obtain $\mathrm{F}_{2}$ seeds. All generations were produced during two growing seasons, 2009-2010 and 2010-2011and as such, the six populations grew together during the same growing season 2011-2012 in a Randomized Complete Block Design with six replications at the Research Field of the College of Agriculture, Salahaddin University in Erbil, Iraq under rainfall conditions [189 $\mathrm{mm}$ precipitation] in $3 \mathrm{~m}$ long plot with $20 \mathrm{~cm}$ between row spacing and $10 \mathrm{~cm}$ between plants, each plot consists of two rows, while the number of analyzed plants per plot varied with generation as follows: 30 plant for $\mathrm{P}_{1}, \mathrm{P}_{2}$ and $\mathrm{F}_{1} ; 70$ plant for $\mathrm{F}_{2}$ and 40 plant for $\mathrm{BC}_{1}$ and $\mathrm{BC}_{2}$. The data were recorded on the mean of ten plants randomly selected from each plot of each replicate: plant height $(\mathrm{cm})$, days to heading, [flag leaf area $\left(\mathrm{cm}^{2}\right)$ (calculated according to Thomas (1975)], spike length $(\mathrm{cm})$, number of spikes/plant, number of 
Mesopotamia J. of Agric.

Vol. (45) No. (4) 2017
ISSN: $2224-9796$ (Online)

ISSN: 1815 - $316 \mathrm{X}$ (Print)

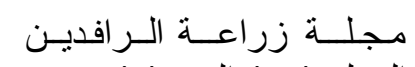

المجلد (45) العدد (4) 2017

grains/spike, 1000-grain weight (g), biomass yield/plant (g), grain yield/plant (g) and harvest index $(\%)$.

Statistical Analysis: Variance analysis test applied according to Randomized Completely Block Design. Mean comparisons of the populations within each cross were made using Duncan's Multiple Range Test at 0.05 probability level for each character (Al-Rawi and Khalaf-Allah, 1980).

Gene Effects Estimation: The genetic model $(m, d$, and $h$ ) was applied when epistasis was absent [non-allelic interactions $(\mathrm{A} \times \mathrm{A}, \mathrm{A} \times \mathrm{D}, \mathrm{D} \times \mathrm{D})$ are not known or observed to occur]; the 3-parameter model can be applied. In this model (joint scaling test), means of the six generations were used to estimate mean $(m)$, additive $(d)$ and dominance $(h)$ gene effects for each character in each cross by the method (additive-dominance model or three parameter model) as described by Jinks and Jones (1958) used the following formulae for estimating of $m, d$ and $h$ components in the absence of non-allelic interaction.

$$
\begin{aligned}
& m=\frac{1}{2} \bar{P}_{1}+\frac{1}{2} \bar{P}_{2}+4 \bar{F}_{2}-2 \bar{B} C_{1}-2 \bar{B} C_{2} \\
& d=\frac{1}{2} \bar{P}_{1}-\frac{1}{2} \bar{P}_{2} \\
& h=6 \bar{B} C_{1}+6 \bar{B} C_{2}-8 \bar{F}_{2}-\bar{F}_{1}-\left(\frac{3}{2}\right) \bar{P}_{1}-\left(\frac{3}{2}\right) \bar{P}_{2}
\end{aligned}
$$

Their variances have been computed using following formulae:

$$
\begin{aligned}
& V_{m}=\frac{1}{4} V \bar{P}_{1}+\frac{1}{4} V \bar{P}_{2}+16 V \bar{F}_{2}+4 V \bar{B} C_{1}+4 V \bar{B} C_{2} \\
& V_{d}=\frac{1}{4} V \bar{P}_{1}+\frac{1}{4} V \bar{P}_{2} \\
& V_{h}=36 V \bar{B} C_{1}+36 V \bar{B} C_{2}+64 V \bar{F}_{2}+V \bar{F}_{1}+\left(\frac{9}{4}\right) V \bar{P}_{1}+\left(\frac{9}{4}\right) V \overline{P_{1}} \text { Now, S.E. } \cdot_{(m)}=\left(V_{m}\right)^{\frac{1}{2}}, \quad S . E_{\cdot_{(d)}}=\left(V_{d}\right)^{\frac{1}{2}} \quad \text {, } \\
& S . E_{\cdot_{(h)}}=\left(V_{h}\right)^{\frac{1}{2}} \text { And, } t_{(m)}=m / S . E_{\bullet_{(m)}}, t_{(d)}=m / S . E_{\cdot_{(d)}}, t_{(h)}=m / S . E_{\bullet_{(h)}} .
\end{aligned}
$$

Since the additive-dominance model was inadequate to explain genetic architecture for researched plant characters, then six parameter model (additivedominance-epistasis model) fitted to generation means to indicate genetically components, using methods outlined by Hayman (1958) and Jinks and Jones (1958), which illustrated by Singh and Chaudhary (1979). Significance of the parameters was tested against their corresponding standard errors.

The following six-parameter model is used for estimation of genetic components according to Hayman (1958).

$m=$ Mean $=\bar{F}_{2}$

$d=$ Additive effect $=\bar{B} C_{1}-\bar{B} C_{2}$

$h=$ Domin ant effect $=\bar{F}_{1}-4 \bar{F}_{2}-\left(\frac{1}{2}\right) \bar{P}_{1}-\left(\frac{1}{2}\right) \bar{P}_{2}+2 \bar{B} C_{1}+2 \bar{B} C_{2} i=$ Additive $\times$ Additive gene interaction $=2 \bar{B} C_{1}+2 \bar{B} C_{2}-4 \bar{F}_{2}$

$j=$ Additive $\times$ Dominance gene interaction $=\bar{B} C_{1}-\left(\frac{1}{2}\right) \bar{P}_{1}-\bar{B} C_{2}+\left(\frac{1}{2}\right) \bar{P}_{2}$

$l=$ Dominance $\times$ Dominance gene interaction $=\bar{P}_{1}+\bar{P}_{2}+2 \bar{F}_{1}+4 \bar{F}_{2}-4 \bar{B} C_{1}-\bar{B} C_{2}$

Their variances have been computed using following formulae:

$$
\begin{aligned}
& V_{m}=V\left(\bar{F}_{2}\right) \\
& V_{d}=V\left(\bar{B} C_{1}\right)+V\left(\bar{B} C_{2}\right) \\
& V_{h}=V\left(\overline{F_{1}}\right)+16 V\left(\bar{F}_{2}\right)+\frac{1}{4} V\left(\bar{P}_{1}\right)+\frac{1}{4} V\left(\bar{P}_{2}\right)+4 V\left(\bar{B}_{1}\right) V_{i}=4 V\left(\bar{B} C_{1}\right)+4 V\left(\bar{B} C_{2}\right)+16 V\left(\bar{F}_{2}\right)
\end{aligned}
$$


$V_{j}=V\left(\bar{B} C_{1}\right)+\frac{1}{4} V\left(\bar{P}_{1}\right)+V\left(\bar{B} C_{2}\right)+\frac{1}{4} V\left(\bar{P}_{2}\right) V_{l}=V\left(\bar{P}_{1}\right)+V\left(\bar{P}_{2}\right)+4 V\left(\bar{F}_{1}\right)+4 V\left(\bar{F}_{1}\right)+16 V\left(\bar{F}_{2}\right)+$

$+16 V\left(\bar{B} C_{1}\right)+16 V\left(\bar{B} C_{1}\right)+16 V\left(\bar{B} C_{2}\right)$

Now, $S . E_{\cdot_{(m)}}=\left(V_{m}\right)^{\frac{1}{2}}$, S.E. $\cdot_{\cdot_{(d)}}=\left(V_{d}\right)^{\frac{1}{2}}$,

$S . E_{\cdot_{(h)}}=\left(V_{h}\right)^{\frac{1}{2}}, S . E_{\cdot_{(i)}}=\left(V_{i}\right)^{\frac{1}{2}}$,

$S . E_{\cdot(j)}=\left(V_{j}\right)^{\frac{1}{2}}, \quad S . E_{\cdot_{(l)}}=\left(V_{l}\right)^{\frac{1}{2}}$.

And, $t_{(m)}=m / S . E_{\cdot_{(m)}}, \quad t_{(d)}=m / S . E_{\cdot_{(d)}}, \quad t_{(h)}=m / S . E_{\bullet_{(h)}}, \quad t_{(i)}=m / S . E_{\bullet_{(i)}}$,

$t_{(j)}=m / S . E_{\cdot_{(j)}}, t_{(l)}=m / S . E_{\cdot_{(l)}}$.

The calculated values of $t$ are to be compared with 1.96 which is a tabulated value of $t$ at $5 \%$ probability level Singh and Chaudhary (1979).

Genetic Parameters: Additive $\left(\mathrm{V}_{\mathrm{A}}\right)$, dominance $\left(\mathrm{V}_{\mathrm{D}}\right)$, additive $\times$ dominance $\left(\mathrm{V}_{\mathrm{AD}}\right)$ and environmental variance $\left(\mathrm{V}_{\mathrm{E}}\right)$ components were estimated according to Kearsey and Pooni (1996):

$$
\begin{aligned}
& V_{E}=1 / 4\left(V P_{1}+V P_{2}+2 V F_{1}\right) \\
& V_{A}=2 V F_{2}-\left(V B C_{1}+V B C_{2}\right) \\
& V_{D}=V B C_{1}+V B C_{2}-V F_{2}-V_{E} \\
& V_{A D}=1 / 2\left(V B C 2-V B C_{1}\right)
\end{aligned}
$$

The significance of $\mathrm{V}_{\mathrm{A}}, \mathrm{V}_{\mathrm{D}}$ and $\mathrm{V}_{\mathrm{AD}}$ were tested by t-test by using the following equations:

$\mathrm{V}_{\mathrm{A}}=\left(2 \times \mathrm{V}_{\mathrm{F} 2}-\mathrm{V}_{\mathrm{BC} 1}-\mathrm{V}_{\mathrm{BC} 2}\right)$

$\mathrm{V}_{\mathrm{D}}=\left(\mathrm{V}_{\mathrm{BC} 1}+\mathrm{V}_{\mathrm{BC} 2}-\mathrm{V}_{\mathrm{F} 2}-\mathrm{V}_{\mathrm{E}}\right)$

$\mathrm{V}_{\mathrm{AD}}=0.5\left(\mathrm{~V}_{\mathrm{BC} 2}-\mathrm{V}_{\mathrm{BC} 1}\right)$

Now, S.E. $\cdot_{\left(V_{A}\right)}=\left(V_{A}\right)^{\frac{1}{2}} ; S \cdot E_{\cdot_{\left(V_{D}\right)}}=\left(V_{D}\right)^{\frac{1}{2}} ; S \cdot E_{\cdot_{\left(V_{A D}\right)}}=\left(V_{A D}\right)^{\frac{1}{2}}$.

Then,

Genotypic variance $V_{G}=V_{A}+V_{D}+V_{A D}$ and phenotypic variance $V_{P}=V_{G}+V_{E}$.

Heritability in broad $\left(h_{\text {b.s. }}^{2}\right)$ and narrow sense $\left(h_{n . s .}^{2}\right)$ was estimated using the following equations:

$h_{\text {b.s. }}^{2}=V_{G} / V_{P}, \quad h_{n . s .}^{2}=V_{A} / V_{P}$

The $\mathrm{V}_{\mathrm{A}}, \mathrm{V}_{\mathrm{D}}$ and $\mathrm{V}_{\mathrm{AD}}$ values were set to zero when estimated variance turned out to be negative. Expected genetic advance was estimated with $10 \%$ selection intensity (i) (selection differential, $\mathrm{i}=1.76$ ) as: $E G A=i \times H_{b . s}^{2} \times \sqrt{V_{P}}$, as well as the percentage of expected genetic advance for the mean was calculated using the following equation: $E G A \%=G A / \bar{X} .100$. The estimate of heterosis over better parent (Heterobeltiosis) and mid-parent was calculated as the following equations:

\section{Heterobeltiosis $=F_{1}-B P ; \quad$ Heterosis $=F_{1}-\overline{M P}$}

Inbreeding depression was expressed as the percent reduction of the $F_{2}$ mean below performance (Toklu and Yagbasanlar, 2007):

Inbreeding depression $(\%)=\frac{F_{1-} F_{2}}{F_{2}} \times 100$ 
Mesopotamia J. of Agric.

Vol. (45) No. (4) 2017
ISSN: 2224 - 9796 (Online)

ISSN: 1815 - $316 \mathrm{X}$ (Print)
مجلــة زراعـة الــر افديـن

المجلد (45) العدد (4) 2017

\section{RESULTS AND DISCUSSION}

The mean values of the two crosses are presented in Table (1). Parents showed difference in all the characters studied in both crosses, except for the spike length, no. of spikes/plant, biomass yield/plant, grain yield/plant and harvest index in Mexipak $\times$ Acsad- 8 cross and for spike length, no. of spikes/plant and no. of grains/spike in Ipa$99 \times$ Attla cross. Mean values of the $F_{1}$ was between parental values for the plant height and days to heading in Mexipak $\times$ Acsad- 8 cross and only for harvest index in Ipa- $99 \times$ Attla cross. Mean values of $F_{1}$ generation greater than the parental of both crosses, while $F_{1}$ generation for days to heading was lower than parents of both crosses. Mean values of the second filial generations $\mathrm{F}_{2}$ was between parental values for the flag leaf area and spike length in Mexipak $\times$ Acsad- 8 cross and for the flag leaf area, spike length and harvest index in Ipa- $99 \times$ Attla cross. For GY in both crosses, the value of $\mathrm{F}_{2}$ generation was better than the parental one. First and second backcrosses showed differences due to parental participation in particular cross. Mean performances of the $\mathrm{BC}_{1}$ and $\mathrm{BC}_{2}$ was greater than the higher parent for all traits except for plant height in Mexipak $\times$ Acsad- 8 cross. Also, for the cross Ipa- $99 \times$ Attla cross, $\mathrm{BC}_{1}$ and $\mathrm{BC}_{2}$ mean was than the top parent for all traits except for plant height and harvest index which revealed that transgressive segregation occurred in this situation. The differences among analyzed generations were sufficient to perform generation mean analysis. Similar results were obtained by Eshghi and Akhundova (2009) in barley and Dvojkovic et al. (2010). Subsequently, because the analysis of variance for traits showed significant differences between generations in both crosses except for spike length and no. of spikes/plant, therefore study the inheritance and analyzing the generation means was carried out.

Table (1): Mean comparison between populations for various characters of the tow crosses.

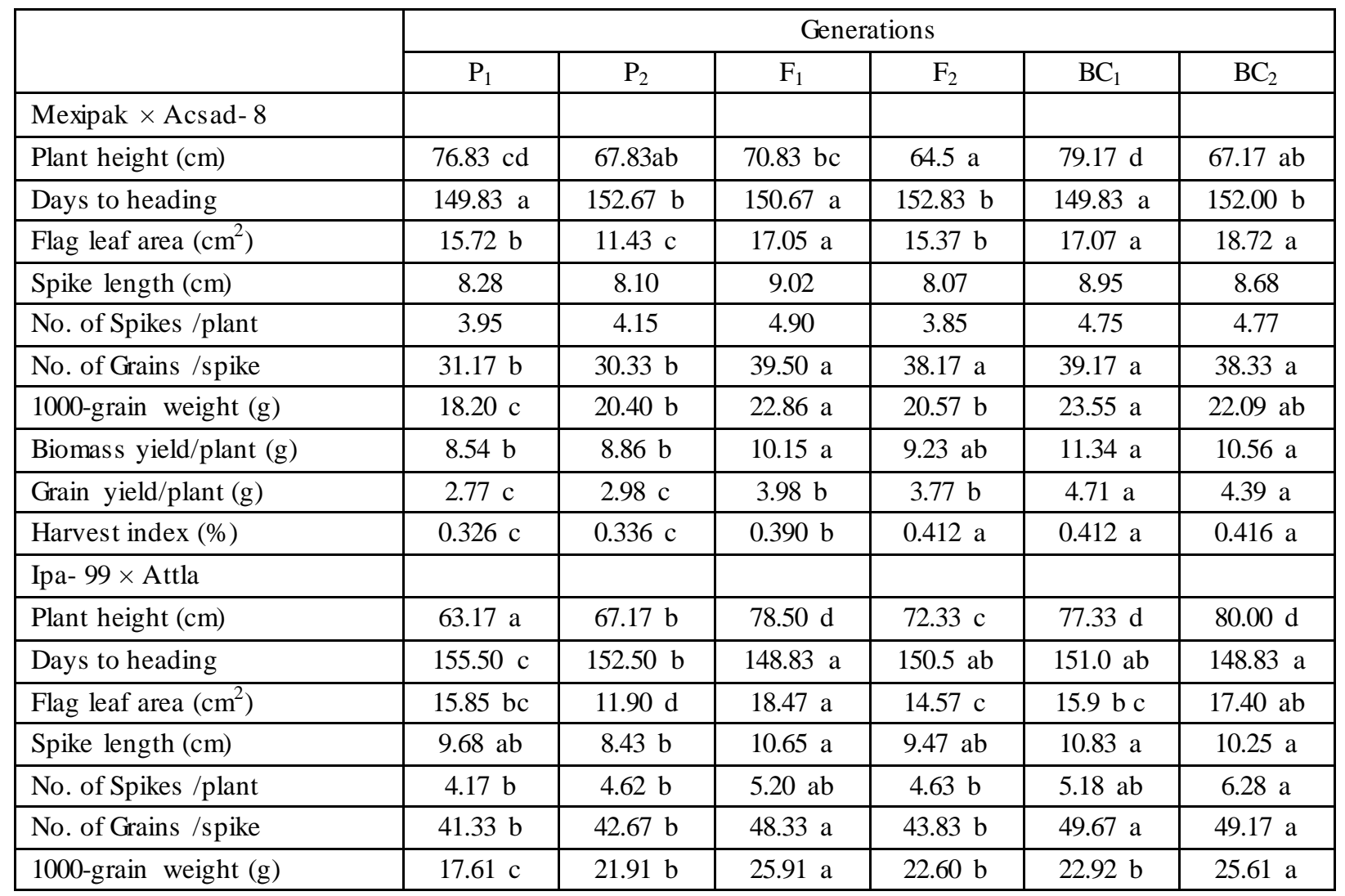


Mesopotamia J. of Agric.

Vol. (45) No. (4) 2017
ISSN: $2224-9796$ (Online)

ISSN: 1815 - $316 \mathrm{X}$ (Print)
مجلــة زراعــة الـر افديـن

المجلد (45) العدد (4) 2017

\begin{tabular}{|l|c|c|c|c|c|c|}
\hline Biomass yield/plant (g) & $13.08 \mathrm{bc}$ & $11.38 \mathrm{c}$ & $16.07 \mathrm{a}$ & $14.67 \mathrm{~b}$ & $15.15 \mathrm{ab}$ & $16.62 \mathrm{a}$ \\
\hline Grain yield/plant (g) & $3.77 \mathrm{c}$ & $4.39 \mathrm{~b}$ & $5.97 \mathrm{a}$ & $4.86 \mathrm{~b}$ & $5.72 \mathrm{a}$ & $4.54 \mathrm{~b}$ \\
\hline Harvest index (\%) & $0.287 \mathrm{c}$ & $0.389 \mathrm{a}$ & $0.374 \mathrm{a}$ & $0.338 \mathrm{~b}$ & $0.380 \mathrm{a}$ & $0.323 \mathrm{~b}$ \\
\hline
\end{tabular}

Means in each row followed by the same letter are not significantly different based on Duncan's Multiple Range Test at 0.05 probability level.

Gene effects depend on the joint scaling test based on three parameter models given in Table (2). In both crosses, the t-test values for most characters were found to be significant, which indicates the inadequacy of additive- dominance model. In this context, non-allelic interaction and linkage may play a part with the additive dominance gene effects in the inheritance of these characters. It was revealed that inheritance of these traits could not be explained by additive-dominance model. These results are in agreement with Aykut et al. (2011). Six parameter model (additivedominance-epistasis model) fitted to generation means to indicate genetically components, which is shown in Table (3). Significance the estimated values of mean effects (m) indicated that most of the studied characters were quantitatively inherited. Additive gene effects (d) were significant for plant height, days to heading and 1000 grain weight in Mexipak $\times$ Acsad- 8 cross while, for all traits except fag leaf area and no. of grains/spike in Ipa- $99 \times$ Attla cross. The negative and positive signs for additive effects depend on which parent is chosen as parent (Awaad, 1996). Significant dominant type of gene effects (h) was fond for all traits in both crosses except biomass yield/plant, grain yield/plant and harvest index in Ipa- $99 \times$ Attla cross. These results suggest that pedigree selection method is a useful breeding program for improving these traits and are in agreement with those find by Salem (2006). Significant epistatic additive $x$ additive type of gene effects (i) was found for all traits except harvest index in Mexipak $\times$ Acsad- 8 cross; Plant height, flag leaf area, spike length, no. of spikes/plant and no. of grains/spike in the Ipa- $99 \times$ Attla cross. Aykut et al. (2011) reported that because of the significance of epistatic gene effects, selection in order to increase these traits should be initiated for next generations. Additive $\times$ dominance epistatic type of gene effects (j) was significant for plant height, days to heading and flag leaf area in Mexipak $\times$ Acsad- 8 cross; plant height, flag leaf area and harvest index in Ipa $99 \times$ Attla cross.

Table (2): Joint scaling test for studied characters of two bread wheat crosses.

\begin{tabular}{|l|c|c|c|}
\hline \multirow{2}{*}{} & \multicolumn{3}{|c|}{ Joint scaling test } \\
\cline { 2 - 4 } & $M$ & $d$ & $h$ \\
\hline Mexipak $\times$ Acsad- 8 & & $4.50 \pm 1.30^{*}$ & $74.17 \pm 28.58^{*}$ \\
\hline Plant height $(\mathrm{cm})$ & $37.67 \pm 12.36^{*}$ & $-1.42 \pm 0.47^{*}$ & $-16.08 \pm 8.76$ \\
\hline Days to heading & $158.92 \pm 3.76^{*}$ & $2.14 \pm 0.23^{*}$ & $33.99 \pm 5.88^{*}$ \\
\hline Flag leaf area $\left(\mathrm{cm}^{2}\right)$ & $3.48 \pm 2.71$ & $0.09 \pm 0.16$ & $7.68 \pm 2.58^{*}$ \\
\hline Spike length $(\mathrm{cm})$ & $5.19 \pm 1.07^{*}$ & $-0.10 \pm 0.10$ & $9.25 \pm 2.61^{*}$ \\
\hline No. of Spikes /plant & $0.42 \pm 1.02$ & $0.42 \pm 1.06$ & $27.92 \pm 7.97^{*}$ \\
\hline No. of Grains /spike & $28.41 \pm 3.38^{*}$ & $-1.10 \pm 0.22^{*}$ & $28.48 \pm 6.12^{*}$ \\
\hline 1000-grain weight $(\mathrm{g})$ & $10.32 \pm 2.70^{*}$ & $-0.16 \pm 0.25$ & $21.33 \pm 5.38^{*}$ \\
\hline Biomass yield/plant $(\mathrm{g})$ & $1.81 \pm 2.01$ & $-0.11 \pm 0.11$ & $11.81 \pm 3.34^{*}$ \\
\hline Grain yield/plant $(\mathrm{g})$ & $-0.23 \pm 1.14$ & $-0.005 \pm 0.011$ & $0.289 \pm 0.232$ \\
\hline Harvest index $(\%)$ & $-0.323 \pm 0.097^{*}$ & & \\
\hline Ipa- 99 $\times$ Attla & & & \\
\hline
\end{tabular}


Mesopotamia J. of Agric.

Vol. (45) No. (4) 2017
ISSN: $2224-9796$ (Online)

ISSN: 1815 - $316 \mathrm{X}$ (Print)
مجلـــة زراعــة الـر افديـن

المجلد (45) العدد (4) 2017

\begin{tabular}{|l|c|c|c|}
\hline Plant height $(\mathrm{cm})$ & $39.33 \pm 7.13^{*}$ & $-2.00 \pm 0.53^{*}$ & $91.33 \pm 17.59^{*}$ \\
\hline Days to heading & $156.33 \pm 3.42^{*}$ & $1.50 \pm 0.30^{*}$ & $-15.83 \pm 7.64$ \\
\hline Flag leaf area $\left(\mathrm{cm}^{2}\right)$ & $5.51 \pm 3.72$ & $1.98 \pm 0.35^{*}$ & $33.99 \pm 5.88^{*}$ \\
\hline Spike length $(\mathrm{cm})$ & $4.76 \pm 1.42^{*}$ & $0.63 \pm 0.17^{*}$ & $12.94 \pm 3.13^{*}$ \\
\hline No. of Spikes /plant & $-0.01 \pm 1.43$ & $-0.23 \pm 0.13$ & $13.36 \pm 3.60^{*}$ \\
\hline No. of Grains /spike & $19.67 \pm 4.51^{*}$ & $-0.67 \pm 0.85$ & $68.00 \pm 10.58^{*}$ \\
\hline 1000-grain weight $(\mathrm{g})$ & $13.09 \pm 3.51^{*}$ & $-2.15 \pm 0.29^{*}$ & $25.21 \pm 7.93^{*}$ \\
\hline Biomass yield/plant $(\mathrm{g})$ & $7.37 \pm 4.66$ & $0.85 \pm 0.28^{*}$ & $20.50 \pm 10.64^{*}$ \\
\hline Grain yield/plant $(\mathrm{g})$ & $3.00 \pm 2.41$ & $-0.31 \pm 0.16$ & $4.47 \pm 6.17^{*}$ \\
\hline Harvest index $(\%)$ & $0.280 \pm 0.130^{*}$ & $-0.050 \pm 0.010$ & $0.130 \pm 0.290$ \\
\hline
\end{tabular}

* Significant at 0.05 probability level.

The negative sign of additive $\mathrm{x}$ dominance $(\mathrm{j})$ interaction in most cases also suggested dispersion of genes in the parents (Khattab et al., 2010). Dominance $\times$ dominance epistatic effect $(l)$ was significant for all traits except for days to heading and harvest index in Mexipak $\times$ Acsad- 8 cross, while significant for all traits except biomass yield/plant, grain yield/plant and harvest index in Ipa- $99 \times$ Attla cross. The signs of (h) and (L) were opposite in most traits and indicated the presence of duplicate epistatic effects. This situation complicates using epistatic gene effects in breeding programs. Due to these results, it is concluded that selection in order to improve of desired genotypes should be done for next generations. Similar findings were found by Sheikh et al. (2009), Eshghi Akhundova (2010) and Aykut et al. (2011) whom previously reported that some sort of intermating followed by selection in later generations can be advisable to improve of traits governed by dominance gene effects with prevalence of duplicate epistasis, while complementary epitasis type of gene effects gave similar signs of (h) and (L) for all other traits in both crosses. Similar results have been reported by Khattab et al. (2010).

Table (3): Estimates of six parameters genetic models for studied characters of the two bread wheat crosses.

\begin{tabular}{|l|c|c|c|c|c|c|}
\hline \multirow{2}{*}{} & \multicolumn{7}{|c|}{ Gene effects } \\
\cline { 2 - 7 } & $m$ & $d$ & $h$ & $i$ & $j$ & $l$ \\
\hline Mexipak $\times$ Acsad- 8 & & & & & & \\
\hline \multirow{2}{*}{ Plant height (cm) } & $64.50^{*}$ & $12.00^{*}$ & $33.17^{*}$ & $34.67^{*}$ & $7.50^{*}$ & $-41.00^{*}$ \\
& \pm 2.64 & \pm 3.14 & \pm 12.56 & \pm 12.29 & \pm 3.40 & \pm 17.19 \\
\hline \multirow{2}{*}{ Days to heading } & $152.83^{*}$ & $-2.17^{*}$ & $-8.25^{*}$ & $-7.67^{*}$ & $-0.75^{*}$ & 7.83 \\
& \pm 0.63 & \pm 0.98 & \pm 3.78 & \pm 3.73 & \pm 1.09 & \pm 5.20 \\
\hline \multirow{2}{*}{ Flag leaf area (cm $\left.{ }^{2}\right)$} & 15.36 & $-1.65^{*}$ & $13.58^{*}$ & $10.10^{*}$ & $-3.79^{*}$ & $-20.42^{*}$ \\
& \pm 0.63 & \pm 0.49 & \pm 2.72 & \pm 2.70 & \pm 0.54 & \pm 3.26 \\
\hline \multirow{2}{*}{ Spike length (cm) } & $8.07^{*}$ & 0.27 & $3.83^{*}$ & $3.00^{*}$ & 0.18 & $-3.85^{*}$ \\
& \pm 0.22 & \pm 0.31 & \pm 1.13 & \pm 1.06 & \pm 0.35 & \pm 0.70 \\
\hline \multirow{2}{*}{ No. of spikes/plant } & $3.85^{*}$ & -0.02 & $4.48^{*}$ & $3.63^{*}$ & 0.08 & $-4.77^{*}$ \\
& \pm 0.18 & \pm 0.36 & \pm 1.04 & \pm 1.02 & \pm 0.37 & \pm 1.66 \\
\hline \multirow{2}{*}{ No. of grains/spike } & $38.17^{*}$ & 0.83 & $11.08^{*}$ & $2.33^{*}$ & 0.42 & $-16.83^{*}$ \\
& \pm 0.70 & \pm 0.78 & \pm 3.49 & \pm 3.22 & \pm 1.31 & \pm 4.94 \\
\hline \multirow{2}{*}{ 1000-grain weight (g) } & $20.57^{*}$ & $1.46^{*}$ & $12.54^{*}$ & $8.99^{*}$ & 2.56 & $-15.94^{*}$ \\
& \pm 0.60 & \pm 0.63 & \pm 2.78 & \pm 2.70 & \pm 2.67 & \pm 3.73 \\
\hline \multirow{2}{*}{ Biomass yield/plant (g) } & $9.23^{*}$ & 0.78 & $8.34^{*}$ & $6.89^{*}$ & 0.94 & $-12.99^{*}$ \\
& \pm 0.31 & \pm 0.79 & \pm 2.04 & \pm 2.00 & \pm 0.83 & \pm 3.49 \\
\hline
\end{tabular}


Mesopotamia J. of Agric.

Vol. (45) No. (4) 2017
ISSN: 2224 - 9796 (Online)

ISSN: 1815 - $316 \mathrm{X}$ (Print)
مجلـــة زراعـة الـر افديـن

المجلد (45) العدد (4) 2017

\begin{tabular}{|c|c|c|c|c|c|c|}
\hline Grain yield/plant (g) & $\begin{array}{c}3.77^{*} \\
\pm 0.09\end{array}$ & $\begin{array}{c}0.33 \\
\pm 0.54\end{array}$ & $\begin{array}{c}4.21 * \\
\pm 1.15\end{array}$ & $\begin{array}{c}3.10^{*} \\
\pm 1.14\end{array}$ & $\begin{array}{c}0.43 \\
\pm 0.55\end{array}$ & $\begin{array}{l}-7.60^{*} \\
\pm 2.23\end{array}$ \\
\hline Harvest index $(\%)$ & $\begin{array}{c}0.412^{*} \\
\pm 0.019\end{array}$ & $\begin{array}{c}-0.004 \\
\pm 0.028\end{array}$ & $\begin{array}{c}0.067 \\
\pm 0.098\end{array}$ & $\begin{array}{c}0.008 \\
\pm 0.096\end{array}$ & $\begin{array}{c}0.001 \\
\pm 0.030\end{array}$ & $\begin{array}{c}-0.222 \\
\pm 0.142\end{array}$ \\
\hline \multicolumn{7}{|l|}{ Ipa- $99 \times$ Attla } \\
\hline Plant height $(\mathrm{cm})$ & $\begin{array}{l}\text { 72.33* } \\
\pm 1.36\end{array}$ & $\begin{array}{l}-2.67^{*} \\
\pm 2.29\end{array}$ & $\begin{array}{l}38.67 * \\
\pm 7.19\end{array}$ & $\begin{array}{l}25.33 * \\
\pm 7.11\end{array}$ & $\begin{array}{l}-0.67 * \\
\pm 2.35\end{array}$ & $\begin{array}{l}-52.67 * \\
\pm 10.88\end{array}$ \\
\hline Days to heading & $\begin{array}{c}150.50^{*} \\
\pm 3.42\end{array}$ & $\begin{array}{l}2.17 * \\
\pm 0.75\end{array}$ & $\begin{array}{l}-7.50 * \\
\pm 3.47\end{array}$ & $\begin{array}{c}-2.33 \\
\pm 3.44\end{array}$ & $\begin{array}{c}0.67 \\
\pm 0.81\end{array}$ & $\begin{array}{c}8.33^{*} \\
\pm 4.89\end{array}$ \\
\hline Flag leaf area $\left(\mathrm{cm}^{2}\right)$ & $\begin{array}{l}14.57^{*} \\
\pm 0.78\end{array}$ & $\begin{array}{c}-1.48 \\
\pm 0.99\end{array}$ & $\begin{array}{l}12.96^{*} \\
\pm 3.75\end{array}$ & $\begin{array}{c}8.37^{*} \\
\pm 3.70\end{array}$ & $\begin{array}{l}-3.46^{*} \\
\pm 1.05\end{array}$ & $\begin{array}{c}-10.32 * \\
\pm 5.20\end{array}$ \\
\hline Spike length $(\mathrm{cm})$ & $\begin{array}{l}9.47^{*} \\
\pm 0.32\end{array}$ & $\begin{array}{c}0.58^{*} \\
\pm 0.29\end{array}$ & $\begin{array}{c}5.89 * \\
\pm 1.43\end{array}$ & $\begin{array}{c}4.30^{*} \\
\pm 1.41\end{array}$ & $\begin{array}{c}-0.04 \\
\pm 0.33\end{array}$ & $\begin{array}{l}-7.05^{*} \\
\pm 1.78\end{array}$ \\
\hline No. of spikes/plant & $\begin{array}{l}4.63^{*} \\
\pm 0.26 \\
\end{array}$ & $\begin{array}{l}-1.10^{*} \\
\pm 0.48 \\
\end{array}$ & $\begin{array}{r}5.21^{*} \\
\pm 1.47 \\
\end{array}$ & $\begin{array}{r}4.40^{*} \\
\pm 1.42 \\
\end{array}$ & $\begin{array}{c}-0.88 \\
\pm 0.50 \\
\end{array}$ & $\begin{array}{l}-8.15^{*} \\
\pm 2.31 \\
\end{array}$ \\
\hline No. of grains/spike & $\begin{array}{l}43.83^{*} \\
\pm 0.95\end{array}$ & $\begin{array}{c}0.50 \\
\pm 1.16\end{array}$ & $\begin{array}{l}28.67^{*} \\
\pm 4.68\end{array}$ & $\begin{array}{l}22.33^{*} \\
\pm 4.44\end{array}$ & $\begin{array}{c}1.17 \\
\pm 1.44\end{array}$ & $\begin{array}{l}39.33^{*} \\
\pm 6.38\end{array}$ \\
\hline 1000-grain weight (g) & $\begin{array}{l}22.60^{*} \\
\pm 0.78\end{array}$ & $\begin{array}{l}-2.70^{*} \\
\pm 0.81\end{array}$ & $\begin{array}{l}12.83^{*} \\
\pm 3.58\end{array}$ & $\begin{array}{c}6.67 \\
\pm 3.50\end{array}$ & $\begin{array}{c}-0.55 \\
\pm 0.86\end{array}$ & $\begin{array}{c}-12.39^{*} \\
\pm 4.73\end{array}$ \\
\hline Biomass yield/plant $(\mathrm{g})$ & $\begin{array}{l}14.67 * \\
\pm 1.01\end{array}$ & $\begin{array}{l}-1.47^{*} \\
\pm 1.14\end{array}$ & $\begin{array}{c}8.70 \\
\pm 4.69\end{array}$ & $\begin{array}{c}4.86 \\
\pm 4.65\end{array}$ & $\begin{array}{c}-2.32 \\
\pm 1.17\end{array}$ & $\begin{array}{l}-11.80 \\
\pm 6.23\end{array}$ \\
\hline Grain yield/plant (g) & $\begin{array}{l}4.86^{*} \\
\pm 0.27\end{array}$ & $\begin{array}{l}1.17^{*} \\
\pm 0.96\end{array}$ & $\begin{array}{c}2.98 \\
\pm 2.24\end{array}$ & $\begin{array}{c}1.08 \\
\pm 2.21\end{array}$ & $\begin{array}{c}1.49 \\
\pm 0.97\end{array}$ & $\begin{array}{l}-1.50 \\
\pm 0.97\end{array}$ \\
\hline Harvest index $(\%)$ & $\begin{array}{c}0.338^{*} \\
\pm 0.027\end{array}$ & $\begin{array}{c}0.412^{*} \\
\pm 0.032\end{array}$ & $\begin{array}{c}0.091 \\
\pm 0.127\end{array}$ & $\begin{array}{c}0.055 \\
\pm 0.125 \\
\end{array}$ & $\begin{array}{l}0.108^{*} \\
\pm 0.035 \\
\end{array}$ & $\begin{array}{c}-0.037 \\
\pm 0.175\end{array}$ \\
\hline
\end{tabular}

The values of (dominance $\times$ dominance) were greater than (additive $\times$ additive) and (additive $\times$ dominance) for most studied traits in both crosses in addition to greater values of dominance gene effect than the additive in most traits. It means that inheritance of these traits was controlled by additive and non-additive genetic effects. Farag (2009) and Khattab et al. (2010) also reported that among the epistatic components, the dominance $x$ dominance was greater in magnitudes than additive $x$ additive and additive $\times$ dominance in most studied traits. In this context, Khattab et al. (2010) referred that when additive effects are larger than the non additive, it is suggested that selection in early segregating generations would be effective, while, if the non-additive portion are larger than additive, the improvement of the characters needs intensive selection through later generation. Estimates of the different phenotypic variance components are presented in Table (4). The additive variance (VA) was larger than dominance variance (VD) for plant height, days to heading, flag leaf area, no. of grains /spike and 1000-grain weight in Mexipak $\times$ Acsad- 8 cross, while for all traits except plant height and no. of spikes plant in Ipa- $99 \times$ Attla cross. On the other hand, the negative (zero) and non-significant estimates of additive variance $\left(\mathrm{V}_{\mathrm{A}}\right)$, dominance variance $\left(\mathrm{V}_{\mathrm{D}}\right)$ and additive $\times$ dominance interaction $\left(\mathrm{V}_{\mathrm{AD}}\right)$ resulted in this experiment could have been due to sampling errors and/or the fact that basic generations are inefficient when used for determining these variances (Novoselovic et al., 2004). 
Mesopotamia J. of Agric.

Vol. (45) No. (4) 2017
ISSN: $2224-9796$ (Online)

ISSN: 1815 - $316 \mathrm{X}$ (Print)

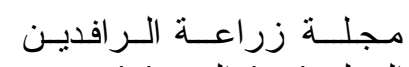

المجلد (45) العدد (4) 2017

Table (4): Estimates of additive $\left(\mathrm{V}_{\mathrm{A}}\right)$, dominance $\left(\mathrm{V}_{\mathrm{D}}\right)$, additive $\times$ dominance $\left(\mathrm{V}_{\mathrm{AD}}\right)$, genotypic $\left(\mathrm{V}_{\mathrm{G}}\right)$, phenotypic $\left(\mathrm{V}_{\mathrm{P}}\right)$ and environmental variance $\left(\mathrm{V}_{\mathrm{E}}\right)$ components for studied characters.

\begin{tabular}{|l|c|c|c|c|c|c|}
\hline & $\mathrm{V}_{\mathrm{E}}$ & $\mathrm{V}_{\mathrm{A}}$ & $\mathrm{V}_{\mathrm{D}}$ & $\mathrm{V}_{\mathrm{AD}}$ & $\mathrm{V}_{\mathrm{G}}$ & $\mathrm{V}_{\mathrm{P}}$ \\
\hline Mexipak $\times$ Acsad- & & & & & & \\
\hline Plant height $(\mathrm{cm})$ & 24.67 & $49.33^{*} \pm 4.97$ & 0.00 & $11.80^{*} \pm 3.44$ & 61.13 & 85.80 \\
\hline Days to heading & 1.84 & $3.53^{*} \pm 1.33$ & $0.16 \pm 0.40$ & $0.32 \pm 0.56$ & 4.01 & 5.85 \\
\hline Flag leaf area $\left(\mathrm{cm}^{2}\right)$ & 0.46 & $6.63^{*} \pm 1.82$ & 0.00 & 0.00 & 6.63 & 7.09 \\
\hline Spike length (cm) & 0.53 & 0.00 & 0.00 & $0.12 \pm 0.34$ & 0.12 & 0.65 \\
\hline No. of spikes/plant & 0.17 & 0.00 & $0.41 \pm 0.64$ & 0.00 & 0.41 & 0.58 \\
\hline No. of grains/spike & 8.86 & $4.60^{*} \pm 1.52$ & 0.00 & 0.00 & 4.60 & 13.46 \\
\hline 1000-grain weight (g) & 1.56 & $3.79^{*} \pm 1.38$ & 0.00 & $0.29 \pm 0.54$ & 4.08 & 5.64 \\
\hline Biomass yield/plant (g) & 0.72 & 0.00 & $2.47 \pm 1.57$ & 0.00 & 2.47 & 3.19 \\
\hline Grain yield/plant (g) & 0.17 & 0.00 & $1.55 \pm 1.24$ & 0.00 & 1.55 & 1.72 \\
\hline Harvest index (\%) & 0.002 & 0.00 & $0.001 \pm 0.03$ & 0.00 & 0.001 & 0.003 \\
\hline Ipa- 99 $\times$ Attla & & & & & & \\
\hline Plant height (cm) & 4.68 & 0.00 & $15.77^{*} \pm 3.97$ & 0.00 & 15.77 & 20.45 \\
\hline Days to heading & 1.63 & $7.27^{*} \pm 1.90$ & 0.00 & 0.00 & 7.27 & 8.90 \\
\hline Flag leaf area (cm $\left.{ }^{2}\right)$ & 1.49 & $2.90^{*} \pm 1.20$ & $0.73 \pm 0.85$ & $1.84 \pm 1.36$ & 5.47 & 6.96 \\
\hline Spike length (cm) & 0.24 & $1.52 \pm 0.87$ & 0.00 & 0.00 & 1.52 & 1.76 \\
\hline No. of spikes/plant & 0.43 & 0.00 & $0.56 \pm 0.75$ & $0.36 \pm 0.60$ & 0.92 & 1.35 \\
\hline No. of grains/spike & 8.87 & $5.40^{*} \pm 1.64$ & 0.00 & $2.95 \pm 1.72$ & 8.35 & 17.22 \\
\hline 1000-grain weight $(\mathrm{g})$ & 1.95 & $6.57^{*} \pm 1.81$ & 0.00 & $0.89 \pm 0.94$ & 7.46 & 9.41 \\
\hline Biomass yield/plant $(\mathrm{g})$ & 1.43 & $9.04^{*} \pm 2.13$ & $0.21 \pm 0.46$ & $1.24 \pm 1.11$ & 10.48 & 11.91 \\
\hline Grain yield/plant (g) & 0.43 & $0.60 \pm 0.55$ & 0.00 & $0.06 \pm 0.25$ & 0.66 & 1.09 \\
\hline Harvest index (\%) & 0.003 & $0.005 \pm 0.05$ & 0.00 & $0.001 \pm 0.04$ & 0.006 & 0.009 \\
\hline
\end{tabular}

$*=$ The values were set to zero when estimated variance turned out to be a negative due to sampling error.

The high narrow and broad sense heritability (0.94) was obtained for flag leaf area in Mexipak $\times$ Acsad- 8 cross, while the high narrow sense heritability (0.86) and high broad sense heritability (0.98) were obtained for spike length and flag leaf area, respectively. Regarding to the inbreeding depression, high positive values $(27.27 \%)$ were obtained for no. of spikes/plant in the Mexipak $\times$ Acsad- 8 cross, while for flag leaf area (26.77\%) and grain yield/plant $(22.61 \%)$ in the Ipa- $99 \times$ Attla cross. However, it was negative for days to heading $(-1.42 \%)$ and harvest index $(-5.30 \%)$ in the Mexipak $\times$ Acsad- 8 cross and for days to heading $(-1.11 \%)$ in the Ipa $99 \times$ Attla cross. The percentage of expected genetic advance ranged from $(1.94 \%)$ for days to heading to $(55.17 \%)$ for grain yield/plant in the Mexipak $\times$ Acsad- 8 cross and from $(2.85 \%)$ for days to heading $(33.54 \%)$ for biomass yield/plant in Ipa- $99 \times$ Attla cross. The wide range of variation among generations was high genetically variation for most traits in both crosses indicated sufficient improvement due to these traits gave high heritability associated with highest genetic advance in these traits.

These results are in harmony with those obtained by Khattab et al. (2010). Heterosis relative to mid-parent (MP) and better parent (BP) Table (5) was found to be positive for most traits in both crosses, while, (MP) was negative for plant height in Mexipak $\times$ Acsad- 8 cross and days to heading in both crosses. As well as (BP) was 
Mesopotamia J. of Agric.

Vol. (45) No. (4) 2017
ISSN: $2224-9796$ (Online)

ISSN: 1815 - $316 \mathrm{X}$ (Print)
مجلـــة زراعــة الـر افديـن

المجلد (45) العدد (4) 2017

negative for days to heading and harvest index in Mexipak $\times$ Acsad- 8 cross and Ipa$99 \times$ Attla cross , respectively. Farag (2009) also found positive heterosis relative to the mid parent and better parent for most of the studied traits except for, plant height.

Table (5): Estimates of heterosis over better parent (BP) and mid parent (MP), inbreeding depression (ID \%), heritability in narrow sense $\left(\mathrm{h}^{2}{ }_{\text {n.s. }}\right)$, heritability in broad sense $\left(\mathrm{h}_{\text {b.s. }}^{2}\right)$ and expected genetic advance under selection (EGA) for studied characters in two bread wheat crosses.

\begin{tabular}{|c|c|c|c|c|c|c|c|}
\hline & $\mathrm{h}_{\mathrm{n} . \mathrm{s} .}^{2}$ & $\mathrm{~h}_{\text {b.s. }}^{2}$ & ID \% & EGA & EGA\% & $\mathrm{BP}$ & MP \\
\hline \multicolumn{8}{|l|}{ Mexipak $\times$ Acsad- 8} \\
\hline Plant height $(\mathrm{cm})$ & 0.57 & 0.71 & 9.82 & 11.57 & 16.28 & 2.80 & -1.50 \\
\hline Days to heading & 0.60 & 0.69 & -1.42 & 2.94 & 1.94 & 0.84 & -0.58 \\
\hline Flag leaf area $\left(\mathrm{cm}^{2}\right)$ & 0.94 & 0.94 & 10.95 & 4.00 & 25.17 & 1.33 & 3.48 \\
\hline Spike length $(\mathrm{cm})$ & 0.00 & 0.18 & 11.78 & 0.26 & 3.11 & 0.74 & 0.83 \\
\hline No. of Spikes/plant & 0.00 & 0.71 & 27.27 & 0.95 & 21.64 & 0.75 & 0.85 \\
\hline No. of Grains/spike & 0.34 & 0.34 & 3.49 & 2.20 & 6.09 & 8.33 & 8.75 \\
\hline 1000-grain weight (g) & 0.67 & 0.72 & 11.11 & 3.01 & 14.14 & 2.46 & 3.56 \\
\hline Biomass yield/plant $(\mathrm{g})$ & 0.00 & 0.77 & 10.03 & 2.42 & 24.74 & 1.29 & 1.45 \\
\hline Grain yield/plant $(\mathrm{g})$ & 0.00 & 0.90 & 5.43 & 2.08 & 55.17 & 1.00 & 1.11 \\
\hline Harvest index (\%) & 0.00 & 0.33 & -5.30 & 0.032 & 8.77 & 0.054 & 0.059 \\
\hline \multicolumn{8}{|l|}{ Ipa- $99 \times$ Attla } \\
\hline Plant height $(\mathrm{cm})$ & 0.42 & 0.77 & 8.53 & 6.13 & 8.39 & 15.33 & 13.33 \\
\hline Days to heading & 0.82 & 0.82 & -1.11 & 4.31 & 2.85 & -3.67 & -5.17 \\
\hline Flag leaf area $\left(\mathrm{cm}^{2}\right)$ & 0.42 & 0.98 & 26.77 & 4.55 & 29.02 & 2.62 & 4.60 \\
\hline Spike length $(\mathrm{cm})$ & 0.86 & 0.86 & 12.50 & 2.01 & 20.32 & 0.97 & 1.60 \\
\hline No. of Spikes/plant & 0.00 & 0.68 & 12.23 & 1.39 & 27.74 & 0.58 & 0.81 \\
\hline No. of Grains/spike & 0.31 & 0.49 & 10.27 & 3.58 & 7.81 & 5.66 & 6.33 \\
\hline 1000-grain weight (g) & 0.70 & 0.79 & 14.68 & 4.27 & 18.76 & 3.70 & 6.15 \\
\hline Biomass yield/plant $(\mathrm{g})$ & 0.76 & 0.88 & 9.53 & 4.86 & 33.54 & 2.99 & 3.84 \\
\hline Grain yield/plant $(\mathrm{g})$ & 0.55 & 0.61 & 22.61 & 1.12 & 22.22 & 1.58 & 1.89 \\
\hline Harvest index $(\%)$ & 0.56 & 0.67 & 10.66 & 0.112 & 32.18 & -0.015 & 0.036 \\
\hline
\end{tabular}

The results of genetic analyses in present study showed that epistatic gene effects were significant for most traits. It can be concluded that, selection for these traits in order to improve the desired genotypes should be done for next generations in both crosses Mexipak $\times$ Acsad- 8 cross and Ipa- $99 \times$ Attla. The dominance effects showed higher values than the additive effects, indicating that dominance gene effects play the major role in controlling the genetic variation of most studied traits. In addition to positive values of heterosis relative to mid and to better parents indicated that dominance direction was toward the best respective parent.

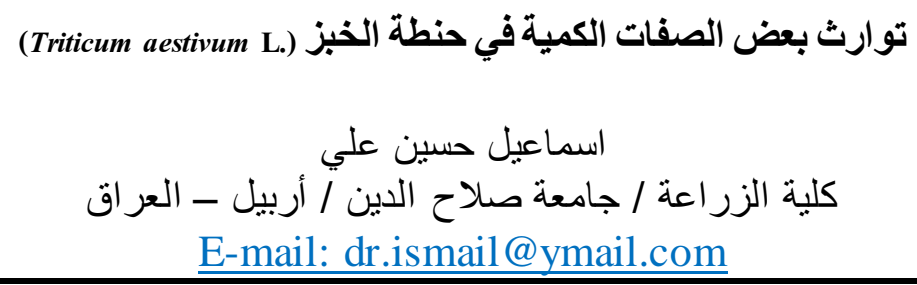




\section{الخلاصة}

استخدمت في هذه التجربة متوسطات ستة مجتمعات ور اثنية هي الأب الأول و الأب الثاني و الجيل الأول

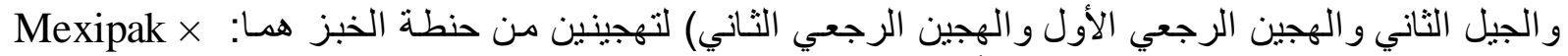
Ipa- 99 × Attlag Acsad- 8

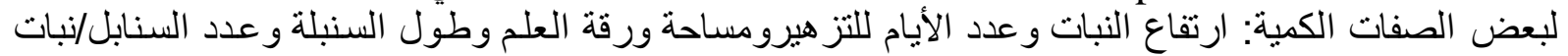

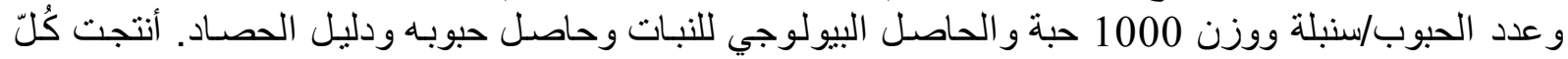

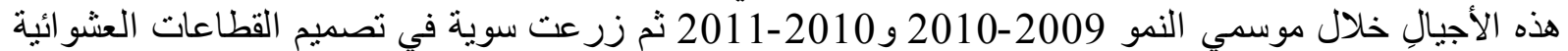

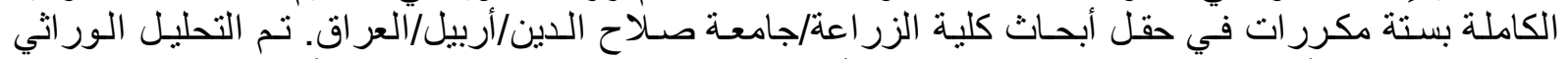

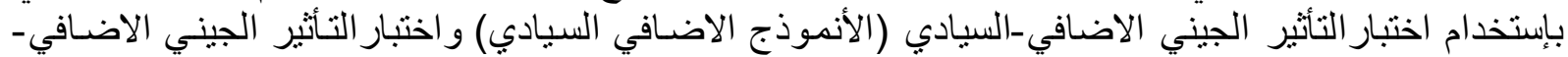

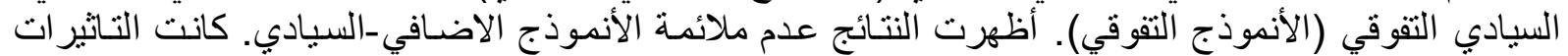

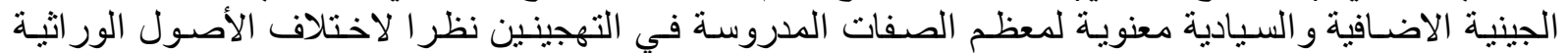

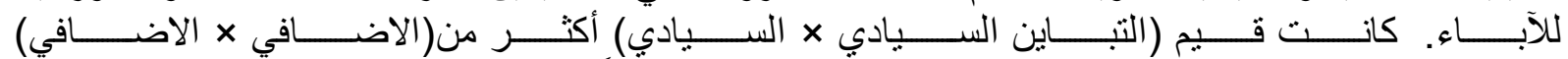

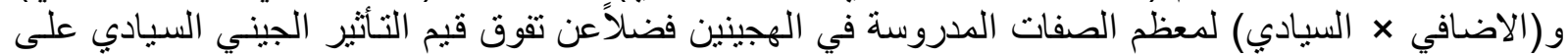

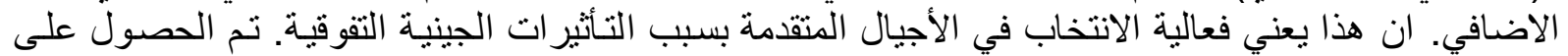

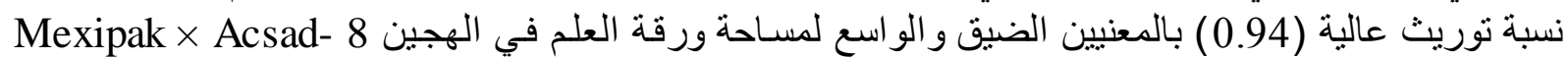

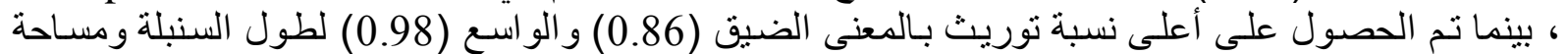

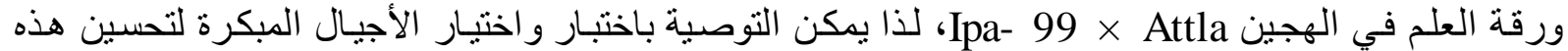

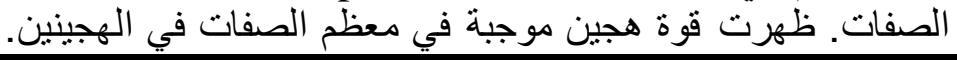

\section{REFERENCES}

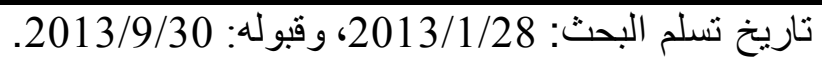

Al-Rawi, K. M. and Khalaf-Allah, A. M. (1980). Design and Analysis of Agricultural Experiments. Mosul Univ. Press. pp:73-77. (In Arabic).

Awaad, H. A. (1996). Genetic system and prediction for yield and its attributes in four wheat crosses (Triticum aestivum L.). Annals of Agriculture Science, 34: 869890.

Aykut T. F., E. Ilker and M. Tosun (2011). Quantitative inheritance of some wheat agronomic traits. Bulgarian Journal of Agriculture Science, 17: 783 -788.

Dvojkovic, K., G. Drezner, D. Novoselovic, A. Lalic, J. Kovacevic, D. Babic and M. Baric (2012). Estimation of some genetic parameters through generation mean analysis in two winter wheat crosses. Periodicum Biologorum, 112(3): 247-251.

Eshghi, R. and E. Akhundova (2009). Genetic analysis of grain yield and some agronomic traits in hulless barley. African Journal of Agricultural Research, 4 (12): 1464-1474.

Eshghi, R. and E. Akhundova (2010). Inheritance of some important agronomic characters in hulless barley. International Journal of Agriculture Biology, 12: 73-76.

Farag, H. I. A. (2009). Inheritance of yield and its components in bread wheat (Triticum aestivum L.) using six parameter model under Ras Sudr conditions. 6th International Plant Breeding Conference, Ismailia, Egypt, P: 90-112.

Grafius, J. E. (1978). Multiple characters and correlated response. Crop Science, 18(6): 931-934

Hayman, B. I. (1958). The separation of epestatic from additive and dominance variation in segregating means. Heredity, 12:371-390.

Jinks, J. L. and R. M. Jones (1958). Estimation of the components of heterosis. Genetics, 43: 223-234. 
Kearsey, M. J. and H. S. Pooni (1996). The Genetical Analysis of Quantitative Traits. Maternal Effects and Non-diploids. $1^{\text {st }}$ edition, Chapman and Hall Press, London. pp: 266-274.

Khattab S. A. M., R. M. Esmail and Abd EL-Rahman M. F. AL-Ansary (2010). Genetical analysis of some quantitative traits in bread wheat (Triticum aestivum L.). New York Science Journal, 3(11): 152-157.

Kumbhar, M. B. and A. S. Larika (1989). Genetic analysis of some yield parameters in Triticum aestivum L. Wheat Information Service, 68: 9-12.

Misra, S. C., V. S. Rao, R. N. Dixit, V. D. Surve and V. P. Patil (1994). Genetic control of yield and its components in bread wheat. Indian Journal of Genetics, 54:77-82.

Munir, M., M. A. Chowdhry and M. Ahsan (2007). Generation means studies in bread wheat under drought condition. International Journal of Agriculture Biology, 9(2): 282-286.

Novoselovic, D., M. Baric, G. Drezner, J. Gunjaca, and A. Lalic (2004). Quantitative inheritance of some wheat plant traits. Genetics and Molecular Biology, 27(1): 92-98.

Salem, Nagwa R. A. (2006) Estimation of genetic variance for yield and yield components in two bread wheat crosses. Journal Agriculture Science, Mansoura Univ., 31(10):6143-6152.

Sharma, S. N. and R. S. Sain (2003). Genetic architecture of grain weight in durum wheat under normal and late sown environments. Wheat Information Service, 96: 28-32.

Sheikh, S., R. K. Behl, S. S. Dhanda and A. Kumar (2009). Gene effects for different metric traits under normal and high temperature stress environments in wheat (Triticum aestivum L. Em. Thell). The South Pacific Journal of Natural Science, 27: 33-44.

Singh, R. K. and B. D. Chaudhary (1979). Biometrical Methods in Quantitative Genetic Analysis. Revised ed. Kalyani Publ., India. pp: 80-88.

Singh, R. P., and S. Subedar (1992). Estimation of genetic parameters through generation means analysis in bread wheat. Indian Journal of Genetics and Plant Breeding, 52(4): 369-375.

Thomas, H. (1975). The growth response to weather of simulated vegetative swards of a single genotype of lolium perenne. Journal Agriculture Science, 84:333-343.

Toklu, F. and T. Yagbasanlar (2007). Genetic analysis of kernel size and kernel weight 848. in bread wheat. Asian Journal of Plant Sciences, 6 (5): 844- 